\title{
Media Pembelajaran Berbasis Android Pada Mata Pelajaran Sistem Operasi Jaringan Kelas XI
}

\author{
Joko Kuswanto ${ }^{1}$, Ferri Radiansah ${ }^{2}$ \\ Dosen Tetap Prodi Teknologi Pendidikan Universitas Baturaja \\ Alamat: Jl. Ki Ratu Penghulu No. 02301 Karang Sari Telp. (0735) 326122 Fax. 321822 Baturaja - 32113 \\ OKU Sumatera Selatan; e-mail: ko.8515@gmail.com
}

\begin{abstract}
The use of instructional media is an inseparable part and is an integration of learning methods used. One example of learning media that can be concretized by utilizing technological developments in the field of education is an android-based learning media. This study aims to develop android-based learning media on the subjects of Network Operating System class XI. The research method used is research development with stages of designing, production, evaluation, and analyzing data by percentage. The results of this study indicate that the android-based learning media developed on the subjects of Network Operating System class $\mathrm{XI}$ is feasible for use in learning by teachers and students. Based on several stages of trial, the learning media is categorized valid with the level of feasibility of $82 \%$ with good criteria. This research is expected to be a medium of learning on the subjects of Network Operating System Class XI and can be useful for teachers, students, and advanced researchers.
\end{abstract}

Keywords: Andorid, Learning Media, Development, Network Operating System

Intisari-Penggunaan media pembelajaran merupakan bagian yang tidak bisa dipisahkan dan sudah merupakan suatu integrasi terhadap metode belajar yang dipakai. Salah satu contoh media pembelajaran yang bisa dikongkritkan dengan memanfaatkan perkembangan teknologi di bidang pendidikan adalah media pembelajaran berbasis android. Penelitian ini bertujuan untuk mengembangkan media pembelajaran berbasis android pada mata pelajaran Sistem Operasi Jaringan kelas XI. Metode penelitian yang digunakan adalah penelitian pengembangan dengan tahapan perancangan, produksi, evaluasi, dan menganalisis data dengan persentase. Hasil penelitian ini menunjukkan bahwa media pembelajaran berbasis android yang dikembangkan pada mata pelajaran Sistem Operasi Jaringan kelas XI sudah layak untuk digunakan dalam pembelajaran oleh guru dan siswa. Berdasarkan beberapa tahapan uji coba, media pembelajaran dikategorikan valid dengan tingkat kelayakan sebesar 82\% dengan kriteria baik. Penelitian ini diharapkan dapat menjadi media pembelajaran pada mata pelajaran Sistem Operasi Jaringan Kelas XI dan dapat bermanfaat bagi guru, siswa, dan peneliti lanjutan.

Kata Kunci: Andorid, Media Pembelajaran, Pengembangan, Sistem Operasi Jaringan

\section{Pendahuluan}

Belajar merupakan suatu proses yang terjadi pada setiap diri orang dari sejak ia lahir sampai akhir hayatnya. Proses belajar dapat terjadi kapan dan dimana saja. Ini bisa dibuktikan dengan berubahnya tingkah laku seseorang yang bisa terjadi pada tingkatan pengetahuan, keterampilan, atau sikapnya. Dalam meningkatkan pengetahuan dan keterampilan siswa dibutuhkan guru yang kreatif.

Ada banyak cara menjadi guru yang kreatif dalam proses pembelajaran, salah satunya dengan memanfaatkan media pembelajaran dalam proses belajar. Penggunaan media pembelajaran merupakan bagian yang tidak bisa dipisahkan dan sudah merupakan suatu integrasi terhadap metode belajar yang dipakai. Kedudukan media pembelajaran memiliki peranan yang penting karena dapat membantu proses belajar siswa. Penggunaan media pembelajaran, bahan belajar yang abstrak bisa di kongkritkan dalam pembelajaran.

Dengan penggunaan media dapat meningkatkan prestasi dan motivasi belajar siswa. Dengan adanya media pembelajaran akan membuat proses pembelajaran lebih menarik, misalnya dari segi tampilan yang dikombinasikan dengan beberapa gambar ataupun animasi. Kemenarikan tampilan fisik sangat mempengaruhi proses pembelajaran, semakin menarik tampilan media maka siswa semakin termotivasi untuk belajar sehingga mempengaruhi hasil belajar siswa (Resiani: 2015). Keindahan, kemenarikan dan adanya interaktivitas dalam suatu 
media pembelajaran merupakan sarana agar peserta didik tidak jenuh dalam mengikuti pelajaran dan efek yang terbesar diharapkan peserta didik dapat termotivasi dan mempermudah dalam menerima materi pelajaran (Fanny: 2013). Salah satu contoh media pembelajaran yang bisa dikongkritkan dengan memanfaatkan perkembangan teknologi di bidang pendidikan adalah media pembelajaran berbasis android.

Pengembangan media pembelajaran tersebut berdasar beberapa pertimbangan: a) dapat dijadikan media belajar mandiri bagi peserta didik baik disekolah maupun diluar sekolah, b) dapat digunakan oleh pendidik sebagai media pembelajaran dalam proses belajar mengajar.

Penelitian yang akan dilakukan bertujuan untuk mengembangkan media pembelajaran berbasis android pada mata pelajaran Sistem Operasi Jaringan kelas XI. Penelitian ini diharapkan dapat menghasilkan produk berupa media pembelajaran yang sesuai dengan kebutuhan siswa kelas XI serta sesuai dengan kurikulum dan silabus yang berlaku, sehingga dapat bermanfaat secara teoretis maupun praktis.

\section{Tinjauan Pustaka}

\section{A. Media Pembelajaran}

Umar (2013 : 8), menyampaikan bahwa media pembelajaran adalah alat, metodik dan teknik yang digunakan sebagai perantara komunikasi antara seorang guru dan murid dalam rangka lebih mengefektifkan komunikasi dan interaksi antara guru dan siswa dalam proses pendidikan pengajaran di sekolah.

\section{B. Manfaat Media Pembelajaran}

Manfaat media pembelajaran menurut Suryani \& Agung (2012 : 156), adalah sebagai berikut :
1. Memperjelas penyajian pesan agar tidak terlalu verbalistis (tahu kata-katanya, tetapi tidak tahu maksudnya).

2. Mengatasi keterbatasan ruang, waktu daya indra.

3. Dengan menggunakan media pembelajaran yang tepat dan bervariasi dapat mengatasi sikap pasif siswa.

4. Dapat menimbulkan persepsi yang sama terhadap suatu masalah.

\section{Android}

Menurut Satyaputra \& Aritonang (2016: 2), andorid adalah sebuah sistem operasi untuk smartphone dan tablet. Sistem operasi dapat diilustrasikan sebagai ‘jembatan’ antara peranti (device) dan penggunanya, sehingga pengguna dapat berintraksi dengan devicenya dan menjalankan aplikasi-aplikasi yang tersedia pada device. Sedangkan menurut Nazrudin Safaat $\mathrm{H}$ dalam M. Ichwan, Fifin Hakiky (2011: 15), android adalah sebuah sistem operasi untuk perangkat mobile berbasis linux yang mencakup sistem operasi, middleware, dan aplikasi. Android adalah sistem operasi untuk telepon seluler yang berbasis linux. Android menyediakan platform terbuka bagi para pengembang untuk membuat aplikasi mereka sendiri. Selanjutnya Murtiwiyati \& Glenn Lauren (2013 : 2), android adalah sebuah sistem operasi untuk perangkat mobile berbasis linux yang mencakup sistem operasi, middleware dan aplikasi.

\section{Sistem Operasi Jaringan}

Menurut Hariyanto dalam Ade Andri Hendriadi, Nono Heryana (2014 : 2), Sistem Operasi adalah sekumpulan rutin perangkat lunak yang berada diantara program aplikasi dan perangkat keras. Semua perangkat lunak berjalan dibawah kendali sistem operasi, mengakses perangkat keras lewat sistem operasi, dan mengikuti aturan-aturan yang dijalankan oleh sistem operasi.

Menurut Yani (2008 : 2), jaringan komputer (computer network) dapat diartikan sebagai dua atau 
lebih komputer yang dihubungkan dengan menggunakan sebuah sistem komunikasi, melalui media atau transmisi atau media komunikasi hingga dapat saling berbagi data, aplikasi, dan berbagi perakngkat keras.

\section{Metodologi Penelitian}

Metode penelitian yang digunakan adalah penelitian pengembangan. Penelitian pengembangan (research and development) berorientasi pada pengembangan produk media pembelajaran (Rusdewanti: 2014). Pengembangan media pembelajaran yang dikembangkan menggunakan metode prosedural (Putra: 2011). Metode yang dilakukan dengan tahapan prosedur pengembangan yaitu (Suryani: 2014): (1) analisis kebutuhan berupa pengumpulan informasi yang berkaitan dengan pengembangan, standar kompetensi, kompetensi dasar, buku yang digunakan; (2) desain pembelajaran berupa analisis dan penetapan standar kompetensi; mengembangkan dan memilih materi pelajaran, membuat rancangan produk; (3) produksi/pengembangan media berupa pengumpulan, memasukkan dan menggabungkan bahan-bahan seperti materi, gambar, animasi, foto, audio, dan lainlain yang sesuai dengan materi yang akan digunakan serta mengetes untuk memastikan apakah pembuatan multimedia sesuai dengan desain yang telah direncakan; dan evaluasi yang berupa uji coba produk yang meliputi 2 tahap, yaitu tahap pertama dilakukan kepada ahli (ahli media ahli desain dan ahli materi), dan tahap kedua dilakukan melalui uji coba satu-satu, kelompok kecil dan uji coba lapangan/kelompok besar (Triyanti: 2015)

\section{Pembahasan}

\section{A. Hasil Penelitian}

Penelitian dan pengembangan ini bertujuan untuk menghasilkan suatu produk media pembelajaran berbasis android. Dalam menghasilkan produk media pembelajaran ini, peneliti melalui beberapa tahap prosedur kerja, yaitu menganalisis dan mengorganisasi materi, merancang desain dan mengaplikasikan kedalam bentuk media pembelajaran berbasis android.

Hasil akhir dalam penelitian ini yaitu media pembelajaran berbasis android yang digunakan sebagai media pembelajaran. Aplikasi terdiri dari halaman-halaman yang saling terhubung menggunakan tombol-tombol.

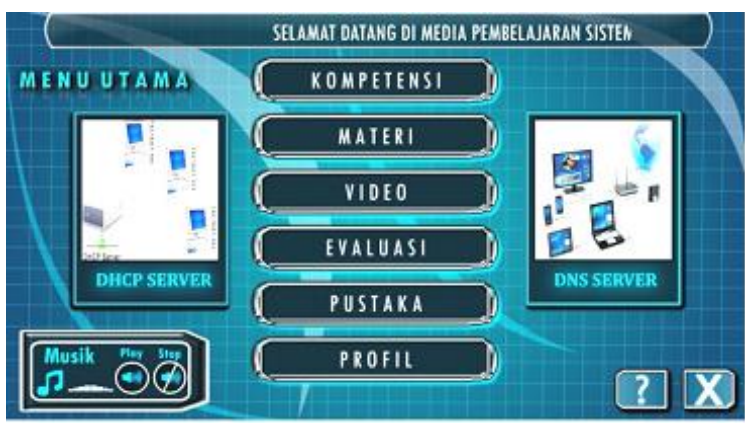

Gambar 1. Tampilan Utama

Halaman utama berisi beberapa tombol yang berfungsi untuk mengakses halaman yang diinginkan. Tombol-tombol yang berada di halaman utama tersebut antara lain tombol Kompetensi, Materi, Video, Evaluasi, Pustaka dan Profil.

Halaman kompetensi berisi informasi mengenai, standar kompetensi dan kompetensi dasar mata pelajaran. Isi dari $\mathrm{SK}, \mathrm{KD}$, dalam media ini disesuaikan dengan silabus pembelajaran Sistem Operasi Jaringan yang ada disekolah.

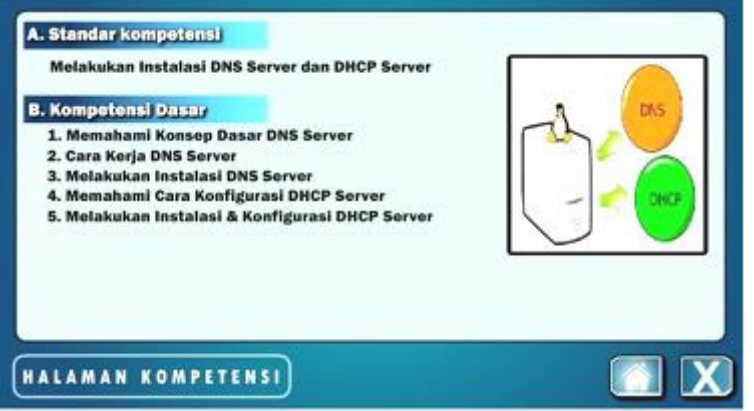

Gambar 2. Tampilan Kompetensi 


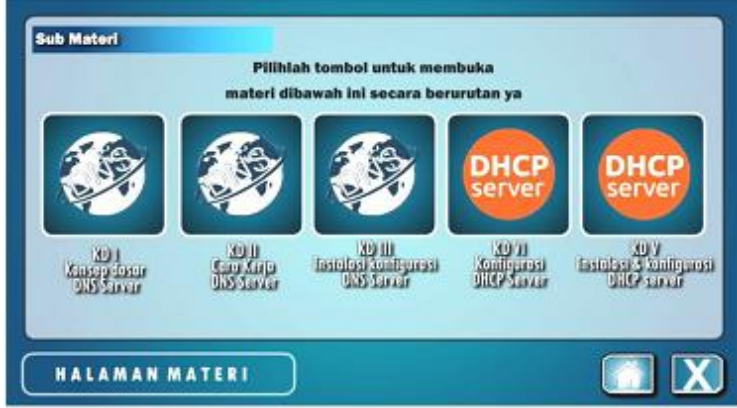

Gambar 3. Tampilan Menu Materi

Halaman menu materi ini merupakan sub menu dari halaman menu utama. Pada halaman ini terdapat tombol-tombol untuk menghubungkan ke materimateri berdasarkan kompetensi dasar. Adapun dalam halaman materi di setiap kompetensi dasar terdapat menu untuk menghubungkan ke materi.

Jika salah satu menu materi di klik atau di pilih sesuai Standar Kompetensi yang ingin dipelajari, maka akan ditampilkan halaman materi berdasarkan Kompetensi Dasar untuk memudahkan pengguna dalam mengakses materi pelajaran. Tampilannya sebagai berikut.

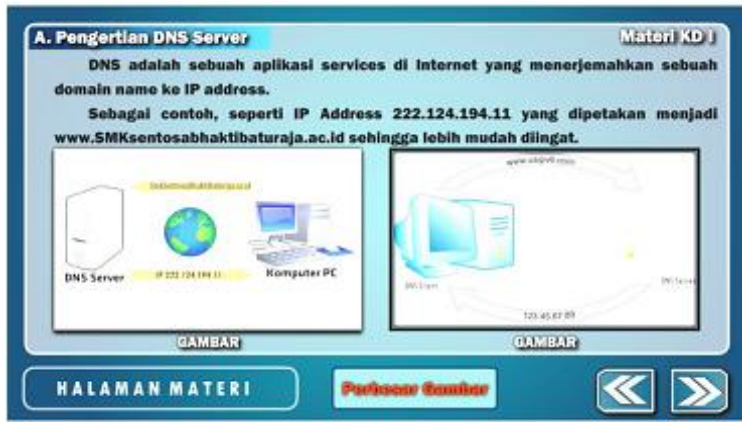

Gambar 4. Tampilan Halaman Materi Sesuai KD

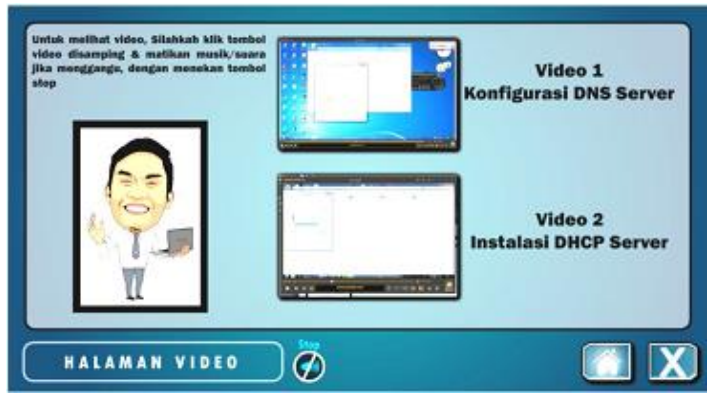

Gambar 5. Tampilan Halaman Video
Awal tampilan halaman video terdapat dua tombol video yang menghubungkan ke video yang akan dituju.

Halaman evaluasi berisi soal-soal yang digunakan untuk mengukur kemampuan siswa melalui produk media pembelajaran. Sebelum masuk ke evaluasi akan ditampilkan petunjuk mengerjakan soal.

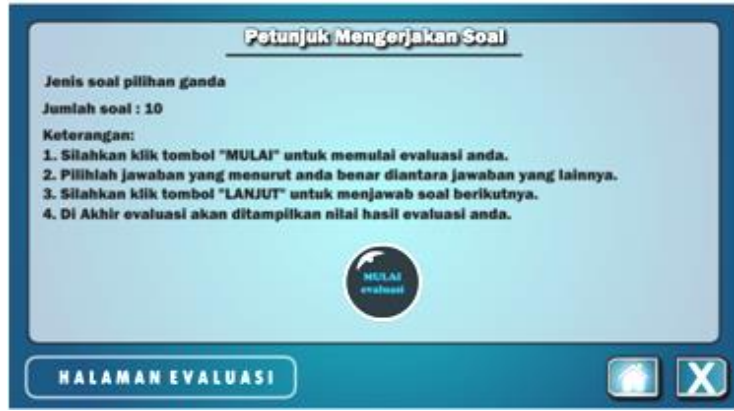

Gambar 6. Tampilan Petunjuk Mengerjakan Soal

Halaman evaluasi berisi soal-soal yang digunakan untuk mengukur kemampuan siswa melalui produk media pembelajaran.

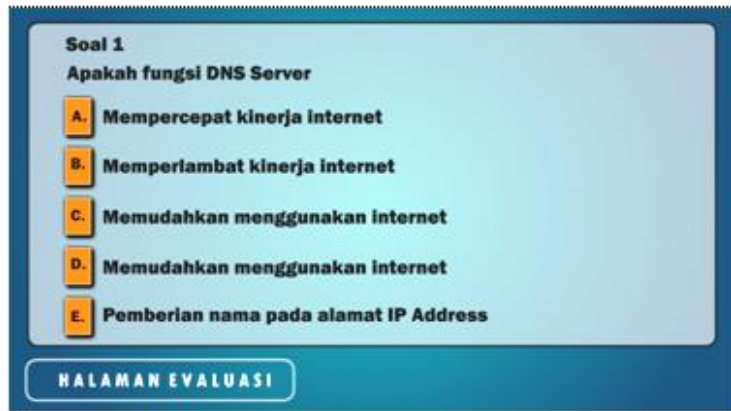

Gambar 7. Tampilan Evaluasi

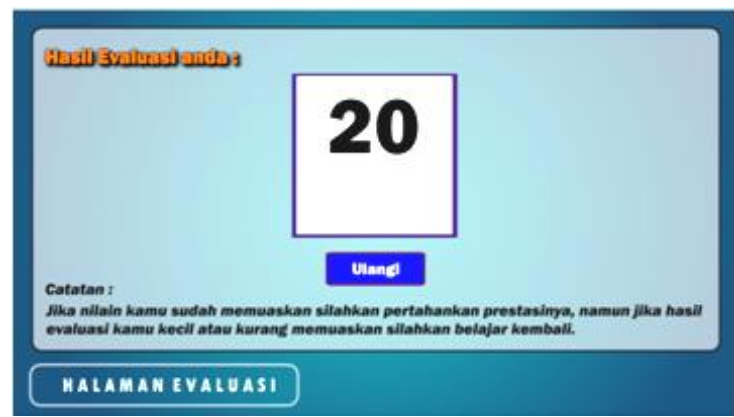

Gambar 8. Tampilan Hasil Evaluasi

Halaman hasil evaluasi akan ditampilkan setelah soal telah selesai dijawab/dikerjakan. Perolehan skor 
atas pengerjaan soal evaluasi akan terlihat setelah soal terakhir selesai dijawab.

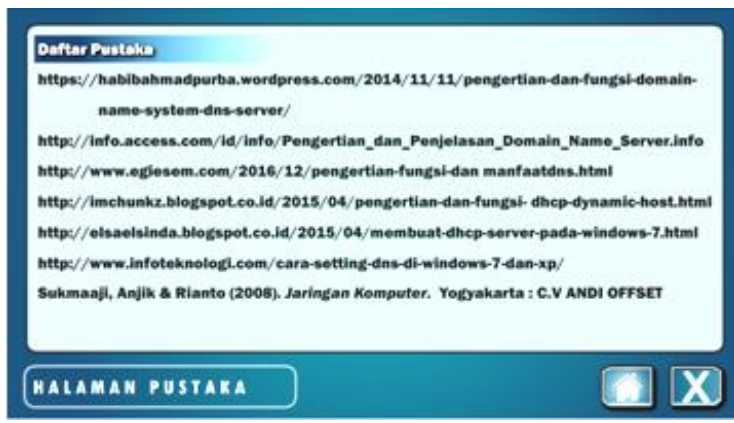

Gambar 9. Tampilan Halaman Pustaka

Pada tampilan halam ini berisikan sumber pustaka materi yang dikemas didalam media pembelajaran ini.

Halaman konfirmasi keluar ini akan muncul jika mengklik tombol keluar yang ada di setiap halaman menu media pembelajaran berbasis android.

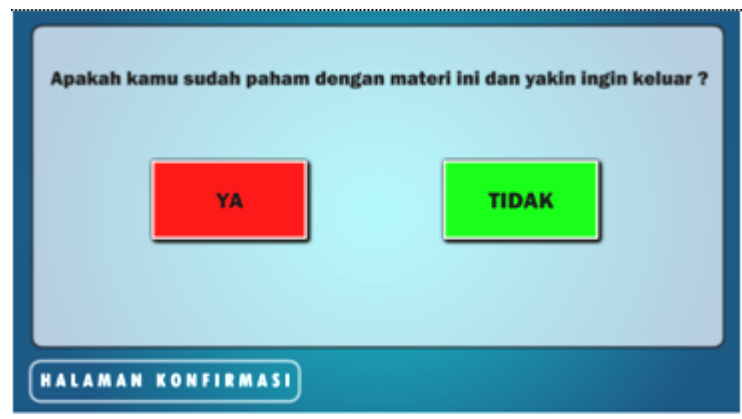

Gambar 10. Tampilan Halaman Konfirmasi Keluar

Jika pengguna memilih tombol "Ya" maka akan keluar dari media pembelajaran berbasis Android. Namun jika pengguna memilih tombol "Tidak" maka akan kembali ke halaman menu utama.

\section{B. Pembahasan}

Media pembelajaran ini dibuat sesuai dengan standar kompetensi dan kompetensi dasar pada mata pelajaran Sistem Operasi Jaringan kelas XI. Media pembelajaran ini sudah melalui tahap validasi oleh ahli, yaitu ahli media, ahli desain, dan ahli materi sebelum akhirnya dilakukan uji coba kelapangan yaitu uji coba perorangan, uji coba skala kecil dan uji coba skala besar. Data hasil uji coba produk media pembelajaran ini adalah: a) hasil uji coba ahli media, diperoleh rata-rata persentase secara keseluruhan dari angket pengujian sebesar $83 \%$ dengan predikat baik, b) hasil uji coba ahli desain, diperoleh rata-rata persentase secara keseluruhan dari angket pengujian sebesar $80 \%$ dengan predikat baik, c) hasil uji coba ahli materi, diperoleh rata-rata persentase secara keseluruhan dari angket pengujian sebesar $84 \%$ dengan predikat baik, d) hasil uji coba skala perorangan, diperoleh rata-rata persentase secara keseluruhan dari angket pengujian sebesar $85 \%$ dengan predikat baik, e) hasil uji coba skala kecil, diperoleh rata-rata persentase secara keseluruhan dari angket pengujian sebesar $85 \%$ dengan predikat baik, f) hasil uji coba skala besar, diperoleh rata-rata persentase secara keseluruhan dari angket pengujian sebesar $82 \%$ dengan predikat baik. Berdasarkan data hasil uji coba yang diperoleh maka media pembelajaran pada mata pelajaran Sistem Operasi Jaringan kelas XI dapat dikatakan layak untuk diterapkan di sekolah.

Media pembelajaran berbasis android ini memiliki kelebihan dan kekurangan. Adapun kelebihan dari media pembelajaran berbasis android ini adalah sebagai berikut :

1. Mudah digunakan, menarik, dan simpel

2. Belajar bisa dimana saja

3. Belajar secara offline atau tidak terhubung ke internet

Namun selain mempunyai beberapa kelebihan, produk ini juga mempunyai kekurangan. Hal ini disebabkan oleh keterbatasan waktu, dana, dan kemampuan peneliti. Adapun kekurangannya yaitu :

1. Butuh handphone android dengan spesifikasi yang cukup tinggi dengan standar minimal RAM 1 GB dan memori internal $4 \mathrm{~GB}$ agar program media pembelajaran tersebut bisa berjalan dengan lancar.

2. Produk hanya membahas materi mata pelajaran Sistem Operasi Jaringan di kelas XI 


\section{Penutup}

Produk yang dihasilkan adalah media pembelajaran berbasis android pada mata pelajaran Sistem Operasi Jaringan kelas XI. Keseluruhan produk media pembelajaran terdiri dari teks, gambar, animasi dan suara, sehingga sangat menarik dan interaktif untuk digunakan sebagai media pembelajaran di sekolah. Media pembelajaran berbasis android ini telah dilakukan tahap validasi ahli, yaitu ahli media, ahli desain, dan ahli materi yang memperoleh kriteria kelayakan "baik". Kemudian uji coba yang dilakukan pada siswa dengan skala perorangan memperoleh kriteria kelayakan "baik", uji coba skala kecil memperoleh kriteria kelayakan "baik", dan uji coba skala besar memperoleh kriteria kelayakan "baik". Jadi dapat disimpulkan bahwa media pembelajaran berbasis android ini memiliki tingkat kelayakan dan kemenarikan produk pada kriteria baik, hal ini dibuktikan dengan hasil pengumpulan data melalui angket terdapat rata-rata persentase butir intstrumen dalam kriteria baik. Berdasarkan data hasil yang diperoleh maka media pembelajaran berbasis android pada mata pelajaran Sistem Operasi Jaringan kelas XI dapat dikatakan layak untuk diterapkan di sekolah.

\section{DAfTAR Pustaka}

[1] Andri Hendriadi \& Nono Heryana. (2014). Pengembangan Sistem Operasi Berbasis Open Source Dalam Pemilihan Paket Distribusi Untuk Menunjang Kegiatan Akademik Dilingkungan Unsika. Jurnal Ilmiah Solusi. Vol 1 (No 2), 19. http://journal.unsika.ac.id/index.php/solusi/issue/archive

[2] Fanny, Arif Mahya, Siti Partini Suardiman. (2013). Pengembangan Multimedia Interaktif Untuk Mata Pelajaran Ilmu Pengetahuan Sosial (IPS) Sekolah Dasar Kelas V. Jurnal Prima Edukasia, Vol: I No. 1.

[3] Suryani, Lili, Ishartiwi. (2014). Pengembangan Game edukasi Bahasa Arab Untuk Mahasiswa UIN Sunan Kalijaga Yogyakarta. Jurnal Inovasi Teknologi Pendidikan, Volume 1 - Nomor 1.

[4] M. Ichwan \& Fifin Hakiky. (2011). Pengukuran Kinerja Goodreads Application Programming Interface (Api) Pada
Aplikasi Mobile Android. Jurnal Informatika. Vol 2 (No 2), 13-21.

[5] Murtiwiyati \& Glenn Lauren. (2013). Rancang Bangun Aplikasi Pembelajaran Budaya Indonesia Untuk Anak Sekolah Dasar Berbasis Android. Jurnal Ilmiah Komputasi. $\left.\begin{array}{lllll}\text { Vol } & 12 & \text { (No } & 2\end{array}\right), \quad 2 . \quad$ http://ejournal.jakstik.ac.id/index.php/komputasi.

[6] Resiani, Ni Kadek, Anak Agung Gede Agung, I Nyoman Jampel. (2015). Pengembangan Game edukasi Interaktif Pada Mata Pelajaran IPS Siswa Kelas VII Semester Genap di SMP N 7 Singaraja Tahun Ajaran 2014/2015. e-Journal Edutech Universitas Pendidikan Ganesha Jurusan Teknologi Pendidikan, Vol: 3 No: 1.

[7] Rusdewanti, Panca Putri, Abdul Gafur. (2014). Pengembangan media Pembelajaran Interaktif Seni Musik untuk Siswa SMP. Jurnal Inovasi Teknologi Pendidikan, Volume 1 - Nomor 2.

[8] Putra, Nusa. (2011). Research \& Development Penelitian dan Pengembangan: Suatu Pengantar. Jakarta: Rajawali Pers.

[9] Satyaputra, Alfa \& Maulina Eva Aritonang. (2016). Let's Build Your Android Apps With Android Studio. Jakarta : PT Elex Media Komputindo.

[10] Suryani, Nunuk \& Agung, Leo. (2012). Strategi Belajar Mengajar. Yogyakarta : Ombak (Anggota IKAPI)

[11] Triyanti, Merti. (2015). Pengembangan Multimedia Interaktif pada Materi Sistem Saraf untuk Meningkatkan Motivasi dan Hasil Belajar Siswa SMA Kelas XI. Jurnal BIOEDUKATIKA, Vol. 3 No. 2 Desember 2015.

[12] Umar. (2013). Media Pendidikan. Jurnal Tarbawiyah. Vol 10 (No 2), 8. http://moraref.or.id/browse/index/549.

[13] Yani, Ahmad. (2008). Panduan Menjadi Teknisi Jaringan Komputer. Jakarta Selatan : PT Kawan Pustaka. 